\title{
The Decoupling of the Nation and the State: Constitutionalizing Transnational Nationhood, Cross-Border Connectivity, Diaspora, and "National" Identity-Affiliation in Asia and Beyond•
}

\author{
Hiroshi FUKURAI* \\ University of California Santa Cruz
}

\begin{abstract}
Since the first Asian Law and Society Conference (ALSA) was held at the National University of Singapore (NUS) in 2016, a number of special sessions have been organized to focus on the deconstruction of the Westphalian transnational order based on the concept of the "nation-state." This dominant hegemony was predicated on the congruence of the geo-territorial boundaries of both the state and the nation, as well as the "assumed integration" of state-defined "citizenship" and another distinctly layered "membership" based on culture, ethnic, religious, and indigenous affiliations. The "nation-state" ideology has thus masked a history of tensions and conflicts, often manifested in the form of oppression, persecution, and genocide directed at the nation and its peoples by the state and its predatory institutions. Our studies have shown that such conflicts between the nation and the state have been observed in multiple regions in Asia, including Kashmir in India; Moro and Islamic communities of Mindanao in the Philippines; Karen, Kachin, and other autonomous nations in Myanmar; West Papua, Aceh, Kalimantan, South Moluccas, Minahasa, and Riau in Indonesia; Kurds in multiple state systems of Iraq, Syria, Turkey, and Iran; and Palestine in Israel, among many other culturally autonomous nucleated communities in Asia and across the world. ${ }^{2}$ The phrase "the nation and the state" was specifically chosen to distinguish and highlight the unique conflictual histories of two geo-political entities and to provide a fundamentally differing interpretation of history, geography, the role of law, and global affairs from the perspectives of nation peoples, rather than from that of the state or international organizations, as traditional analyses do. The Westphalian "nation-state" hegemony led to the inviolability of the state's sovereign control over the nation and peoples within a
\end{abstract}

- I wish to thank Queensland University of Technology (QUT) Professor Leon Wolff, who helped to organize the Third Asian Law and Society Association (ALSA) Conference at Bond University in the Gold Coast, Australia on 30 November-2 December 2018.

* Correspondence to Hiroshi Fukurai, UC Santa Cruz, 1156 High Street, Santa Cruz, CA 95064, USA. E-mail address: hfukurai@ucsc.edu.

1. For the first collective essays of transnational, socio-legal orders and issues in East Asia, see Miyazawa et al. (2015).

2. See Hiroshi Fukurai (2018) for the first publication on the subject of the "decoupling of the state and the nation," which was based on the ALSA conference presentation. A number of articles have also begun to question the predatory impact of "top-down" state policies upon ethnic groups, religious minorities, and indigenous communities in Asia. See e.g. Trzcinski \& Upham (2014) in Cambodia; Otto (2015) in Indonesia; Chopra (2017) and Dutta (2017) in India; Welikala (2016) in Sri Lanka; and Fukurai (2019) in other parts of the world. 
state-delimited territory. The state then began to engage in another predatory project: to strengthen and extend its international influence over other states and, thus, the nations within these states, by adopting new constitutional provisions to offer cross-border "citizenship" to diasporic "ethnic-nationals" and descendants of "ex-migrants" who now inhabit foreign states. The nations have similarly capitalized on constitutional activism by erecting their own Constitutions to explore collaboration with other nations, as well as diasporic populations of their own, in order to carve out a path toward the nations' independence within, and even beyond, the respective state systems. The "constitutional" activism sought by the state and the nation has become an important political vehicle with which to engage in possible collaboration with diasporic "ethno-nationals" and ex-migrant communities, in order to further assert political influence and strengthen trans-border politics of the state and the nation. Three articles included in this issue investigate such constitutional activism of cross-border politics and transnational collaborations in Asia, the Americas, Europe, and other regions across the globe.

Keywords: the Constitution, the state, the nation, diaspora, trans-border politics, Asia, Europe, the Americas

\section{INTRODUCTION: THE DECOUPLING OF THE NATION AND STATE}

An important critical discussion of the decoupling of the nation and state was held at the 2018 ALSA conference at Bond University in the Gold Coast, Australia in the session entitled "Constitutionalizing Transnational Nationhood, Cross-Border Connectivity and National Identity." This session was chaired by renowned constitutional law scholar David Law of Washington University, St. Louis, who also served as the discussant in the panel. The critical comments and suggestions provided by Professor Law on the papers accepted for the conference presentation were later incorporated into the final preparation of those papers selected for publication in this issue of the Asian Journal of Law and Society.

The first article, "Nation v. State: Constitutionalizing Transnational Nationhood, Creating Ethnizens and Engaging with Kin-Foreigners in Europe and Asia," by Yonsei University Professor Chulwoo Lee, examines the constitutional bases for, and regulations on, diasporaengagement policies and kin-minority politics. Professor Lee provides a critical overview of the effects of state Constitutions and government policies related to engagement with non-citizens, or "nation people," who are bound by strong psychological commonality and shared history in Asia, Eastern Europe, former Soviet republics, and other parts of the world. The article begins with a critical analysis of the "ethno-national kin" that re-emerged after the deconstruction of the Soviet Union in 1991 as well as the dissolution of former Yugoslavia in the 1990s and 2000s. Professor Lee then explores diverse modes of diasporic engagement policies by interrogating "ethnizenship," the neologism referring to non-citizen, yet "ethnic-national," groups. By employing this concept, Professor Lee provides a critical analysis of the decoupling of the state and nation by interrogating the political ramifications of varied forms of geo-politically manifested "borders" as well as the state's "abilities" to draw the demarcation lines of sovereignty. His study further explores the dimension of co-ethnics, kin-minorities, and other "national" bondages by examining European and Asian histories of diasporic engagement laws and governance policies, thereby bringing together the critical literature on the historically entrenched notions of "nationalism" and national minorities of Europe, and the critical literature on 
the trans-border strategies of migrant-sending states for political and geo-strategic purposes and realities.

The second article, "The State Constitution v. the Nation Constitution: Original Nations' 'Sovereignty-Building' Projects in Asia, North America and Beyond," is by ALSA President and UC Santa Cruz Professor Hiroshi Fukurai. Instead of focusing on the emergence of constitutional provisions of the state and their impact on diasporic engagement for geo-political purposes of the state, this article explores constitutional activism by the nation, undertaken to assert political rights under both domestic and international law, and to attain independence and the right to self-determination apart from the state supervision. Specifically, the paper looks into the Nation of Lakota in North America, its constitutional amendment, and its efforts to secede from US jurisdiction and to declare the nation's independence, thereby providing the important template for autonomous nations across the globe to attain their independence and right to self-determination. The article provides a critical investigation of an array of both domestic and international laws used by the Nation of Lakota in order to complete the withdrawal of its political ties and legal obligation from the US. Also explored is the ongoing constitutional activism of other nations in North America, Asia, and various regions of the world, in their efforts to attain sovereignty and independence within, and beyond, the respective state systems.

The third article, "Constitutionalizing Trans-Border Nationhood: From Latin American Perspectives," is by Professor Hee-Moon Jo of Hankuk University of Foreign Studies in Korea. After reviewing the emergence of "ethnic-national" policies of Korea, as well as of European and Latin American states, Professor Jo critically interrogates the greater diasporic connections promoted by Constitutions and by diaspora-engaging policies of the state system related to the aggressive expansion of trans-border outreach to overseas "ethnic-nationals." Professor Jo observes that Latin American states and other countries in the Western Hemisphere, including the US, were relatively weak on the policies of diasporic kin-nationalism, perhaps due to settler-state colonialism that relied on the genocide of indigenous nations and forced importation of Africans under the system of slavery. Professor Jo finds that, after the globalization of 1990, varied forms of diasporic engagement polices began to emerge among Latin American states, most prominently in Colombia, in which constitutional provisions and greater diasporic engagements became an effective means of indirectly increasing the state power by actively inducing the trans-state political and economic participation of domicile countries. Professor Jo notes that these strategies by Latin American states and some Asian countries have expanded the international influence of the mother country by sending out de facto "national" out-migrants to the targeted foreign state territories. His article also investigates other legal provisions of diasporic connections, and constitutional foundations supporting such policies, from a political perspective as well as a human rights perspective.

\section{CONCLUSION}

A great number of conflicts continue in various parts of the world today, and many of these are fought between the state and the nation. In an era in which such ongoing struggle continues to pose great challenges in Asia and other parts of the global community, a third 
ALSA conference was held at Bond University in the Gold Coast, Australia in December 2018. The successful conference attracted many scholars, researchers, and legal advocates from multiple countries and regions around the globe, including the Philippines, Afghanistan, India, Indonesia, Malaysia, Thailand, Vietnam, Georgia, Vanuatu, Hong Kong, and Macau, as well as the US, Japan, Canada, South Korea, People's Republic of China, Taiwan, Singapore, Germany, Sweden, Poland, the Czech Republic, and others. Among these countries and regions are some who have been involved in the historical legacy of hostilities between the state and the nation.

Some states have recently shifted their strategic approach to increasing their power and political outreach over other states and nations by extending "citizenship" to the diasporic population of "ethnic-nationals" and descendants of ex-migrants who now inhabit foreign states. This new constitutional provision has become an effective instrument of these states, used to stimulate a greater diasporic engagement and to increase state influence over the political affairs of foreign states and nations. The nations have also begun to institute their own Constitutions to explore potential collaborations with other nations and their diasporic populations in order to seek a path toward the nation's independence and attain the right to self-determination within, or even beyond, the state jurisdiction. It is our hope that this constitutional activism will lead not to the extension of colonial domination and outreach over other states and nations, but to the creation of more robust legal mechanisms to promote the human dignity and human rights of nation peoples and "ethnic-nationals" overseas, as well as to restore and preserve the cultural and biological diversities of the nations' ancestral homelands, which future generations of both the nation and the state will surely need for their survival in the coming decades and beyond.

\section{REFERENCES}

Chopra, Surabhi (2017) "Massacres, Majorities and Money: Reparation after Sectarian Violence in India." 4 Asian Journal of Law and Society 157-90.

Dutta, Sagnik (2017) "From Accommodation to Substantive Equality: Muslim Personal Law, Secular Law, and the Indian Constitution 1985-2015." 4 Asian Journal of Law and Society 191-227.

Fukurai, Hiroshi (2018) "Fourth World Approaches to International Law (FWAIL) and Asia's Indigenous Struggles and Quests for Recognition Under International Law." 5 Asian Journal of Law and Society 221-31.

Fukurai, Hiroshi (2019) “Original Nation Approaches to 'Inter-National' Law (ONAIL): Decoupling of the Nation and the State and the Search for New Legal Orders." 26 Indiana Journal of Global Legal Studies 199-261.

Miyazawa, Setsuo, Weidong Ji, Hiroshi Fukurai, Kay-Wah Chan, \& Matthias Vanhullebusch (2015) East Asia's Renewed Respect for the Rule of Law in the 21st Century: The Future of Legal and Judicial Landscapes in East Asia, Boston: Brill Nijhoff.

Otto, Jan Michiel (2015) "Indonesian Opposition in the Colonial Municipality: A Minahasser in Bandung." 2 Asian Journal of Law and Society 169-93.

Trzcinski, Leah M., \& Frank K. Upham (2014) "Creating Law from the Group Up: Land Use in Post-Conflict Cambodia." 1 Asian Journal of Law and Society 55-77.

Welikala, Sepalika (2016) "Community Mediation as a Hybrid Practice: The Case of Mediation Boards in Sri Lanka." 3 Asian Journal of Law and Society 399-422. 